\title{
In vitro Uterotonic Effects of Ethanolic Fruit Extract of Picralima nitida (Stapf) on Isolated Uterine Smooth Muscles of Rats.
}

\author{
Edmund C. Mbegbu ${ }^{1}$, Izuchukwu S. Ochiogu ${ }^{2}$, Ebere O. Odirichukwu ${ }^{3}$, \\ Chiadikobi E. Onyia ${ }^{4}$, Ernest C. Nweze ${ }^{5}$, Oluwa A. Agbonu ${ }^{6}$, Chukwuka N. \\ Uchendu $^{1}$ \\ ${ }^{I}$ Department of Veterinary Physiology and Pharmacology, University of Nigeria, Nsukka, Nigeria \\ ${ }^{2}$ Department of Veterinary Obstetrics and Reproductive Diseases, University of Nigeria, Nsukka, Nigeria \\ 3 South-East Zonal Biotechnology Centre, University of Nigeria, Nsukka, Nigeria \\ ${ }^{4}$ Department of Veterinary Surgery and Theriogenology, Michael Okpara University of Agriculture, Umudike, Nigeria \\ ${ }^{5}$ Department of Veterinary Physiology and Pharmacology, Michael Okpara University of Agriculture, Umudike, Nigeria \\ ${ }^{6}$ Department of Veterinary Physiology and Pharmacology, University of Abuja, Nigeria
}

\begin{abstract}
Effects of aqueous ethanolic fruit extract of Picralima nitida (EFEPN) on uterine contractility were investigated using rat model. Uterine muscle strips were harvested from sexually mature non-gravid female rats weighing 200-250 g. In each experiment, strip of about $1 \mathrm{~cm}$ was mounted in a $35 \mathrm{ml}$ organ bath containing Krebs' physiological salt solution, connected to an isometric electronic force displacement transducer and an oscillograph. The following drugs were used as receptor agonists or antagonist: Verapamil (0.02 - $0.2 \mu$ mol), Salbutamol ( $0.2 \mu \mathrm{mol})$, Isoprenaline $(0.1 \mu \mathrm{mol})$, Adrenaline $(9.1 \mathrm{nmol})$, Propranolol $(1.0 \mu \mathrm{mol})$, and Prazosin $(10.0 \mathrm{nmol})$. Both the extract and the standard drugs were applied at concentrations corresponding to the final bath concentration. The extract was found to induce a dose-dependent myometrial contraction at concentrations ranging from $\quad 0.035-0.28 \mathrm{mg} / \mathrm{ml}$, whereas concentrations above this range caused a progressive relaxative effect on the uterine muscle tissue. The effective concentrations $\left(E C_{50}\right)$ were $0.056 \mathrm{mg} / \mathrm{ml} \mathrm{and} 1.06 \mathrm{mg} / \mathrm{ml} \mathrm{for}$ contractile and the relaxative responses respectively. The extract did not elicit any contractile response in a physiological salt solution devoid of calcium ions. The contractile response evoked by a fixed concentration of the extract $(0.07 \mathrm{mg} / \mathrm{ml})$ decreased as the concentration of verapamil $(0.02-0.2 \mu \mathrm{mol})$ increased. The extract $(0.07 \mathrm{mg} / \mathrm{ml})$ did not restore the spontaneous myometrial contraction previously abolished by adrenaline (9.1 nmol) and a selective $\beta$-adrenergic receptor agonist, salbutamol (0.2 $\mu$ mol) respectively. However, about $26.3 \%$

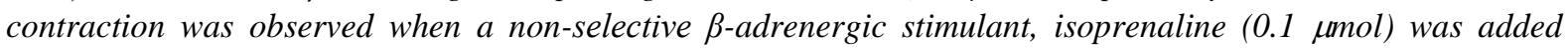
simultaneously with the extract. Also, propranolol $(0.3 \mu \mathrm{mol})$ potentiated the contractile response of this extract. Again, when $\alpha$-adrenoceptors of the uterine tissue were selectively blocked by prazosin (10 nmol), the extract did not produce any contractile effect. From this study, it was concluded that EFEPN has the capacity to induce myometrial contraction at a lower concentration, possibly through mobilization of extracellular calcium ions and stimulation of the $\alpha$-adrenoceptors
\end{abstract}

Keywords Picralima nitida, myometrium, contraction

\section{Introduction}

Uterotonics are required to place the global population, which is estimated to reach 8.9 billion by the year 2050 (far higher than the 2004 estimate of 6.4 billion) under control (Population bulletin, 2004; Pierre, et al., 2010). Regulation of uterine tonicity is of paramount importance in female reproductive function; notably in the induction of labour and prevention of abortion. Drugs are usually employed in the modulation of uterine contractility. Majority of the synthetic uterotonic drugs have accompanying side effects, and are not often cost effective, hence the quest for suitable alternatives. Picralima nitida is a medicinal plant with folkloric reputation of influencing uterine muscle function, as the fruits are indicated for the therapeutic management of dysmenorrhoea (Jiofack, et al., 2009). It has been shown to possess anti-diarrheic (Kouitcheu, et al., 2006; Kouitcheu, 2007), anti-diabetic (Aguwa, et al., 2001), analgesic (Duwiejua, et al., 2002), opioid (Menzies, et al., 1998), anti-plasmodial (Ezeamuzie, et al., 1994), antimicrobial (Fakeye, et al., 2004), anti-inflammatory (Obiri, 1997; Duwiejua, et al., 2002), anti-pyretic (François et al., 1996), trypanocidal (Wosu and Ibe, 1989), as well as anti-leishmanial (Iwu, et al., 1992) activities. The bark is also used to prepare remedies to male sexual impotence (Adjanohoun et al., 1996). Picralima nitida (Stapf) is a bonafide member of the family Apocynaceae and restricted in distribution to African rain forest regions. It is known as limeme (Congo), Eban, Obero (Gabon), Erin (Yoruba), Osuigwe (Igbo), Bamborutuk, Eban (Cameroon).

From the foregoing, it is obvious that several works have diversely investigated the effects of either the crude extract or purified alkaloids from Picralima nitida, but not on the uterus. The objectives of the study therefore 
were to: (i) determine the in vitro effects of aqueous ethanolic fruit extract of Picralima nitida on isolated uterine smooth muscle strips and (ii) investigate the possible mechanism(s) of action of this extract.

\title{
II. Materials and methods
}

Physiological salt solution (PSS)

Fresh Krebs solution was used, having the following composition in grams per litre: $\mathrm{NaCl} 6.9 \mathrm{~g}$; $\mathrm{KCl} 0.35 \mathrm{~g}$; $\mathrm{CaCl} 0.28 \mathrm{~g} ; \mathrm{MgSO}_{4} .7 \mathrm{H}_{2} \mathrm{O} 0.29 \mathrm{~g} ; \mathrm{KH}_{2} \mathrm{PO}_{4} 0.16 \mathrm{~g} ; \mathrm{NaHCO}_{3} 2.1 \mathrm{~g}$; Glucose $2.0 \mathrm{~g}$; and distilled water up to 1 litre.

\section{Nominally $\mathrm{Ca}^{2+}$-free physiological salt solution}

Nominally $\mathrm{Ca}^{2+}$-free physiological salt solution was prepared by deliberate exclusion of calcium chloride $(\mathrm{CaCl})$ from the normal composition of Krebs physiological salt solution; that is, $\mathrm{NaCl} 6.9 \mathrm{~g}$; $\mathrm{KCl} 0.35 \mathrm{~g}$; $\mathrm{MgSO}_{4} .7 \mathrm{H}_{2} \mathrm{O} 0.29 \mathrm{~g} ; \mathrm{KH}_{2} \mathrm{PO}_{4} 0.16 \mathrm{~g} ; \mathrm{NaHCO}_{3} 2.1 \mathrm{~g}$; Glucose $2.0 \mathrm{~g}$; and distilled water up to 1 litre.

\section{Plant material and its extraction}

Mature unripe fruits of Picralima nitida (Stapf) were collected in November, 2010, from Ozubulu, Anambra State of Nigeria by an herbalist, Mr. Hyacinth Oselo. Botanical identification was performed with the aid of a freshly collected fruits and leaves, at the International Centre for Ethnomedicine and Drug Development, Nsukka, where a voucher number INTERCEDD/32 has already been designated for Picralima nitida (Stapf). Fruits of Picralima nitida were cut into small pieces and dried under sunlight and subsequently pulverized with manual grinder into coarse powder. Three hundred and ninety five (395) grams of the powder was poured into an improvised thimble. The plant material was extracted first with 1.8 litres of petroleum ether $\left(60-80^{\circ} \mathrm{C}\right)$ for 48 hours, followed by 2.5 litres of $30 \%$ aqueous ethanol for another 72 hours. In each case, the set ups were agitated every 2 hours. The filtrates were poured into petri dishes, and solvents allowed to evaporate at room temperature. The percentage yield was calculated using the following formula: yield $=$ weight of extract divided by the weight of the starting material multiplied by 100. The resultant dark-brown, semisolid extract was preserved at $4^{\circ} \mathrm{C}$ until usage.

\begin{abstract}
Animals
Non-pregnant sexually mature female Sprague Dawley rats, weighing between $200-250$ grams were used for the in vitro experiments. The animals were procured from Laboratory Animal unit of the Faculty of Veterinary Medicine, University of Nigeria, Nsukka. Prior to the commencement of the experiments, the animals were acclimatized for a period of three weeks. They were kept in metal cages under room temperature, with 12-hour light and 12-hour dark cycle. Clean water and feed (Vital® Growers feed, GCOML, Jos, Nigeria) containing $14.5 \%$ crude protein were supplied ad libitum.
\end{abstract}

\section{Tissue preparation}

The rats were primed with intraperitoneal injection of $0.1 \mathrm{mg} / \mathrm{kg}$ of stilbesterol 24 hours before the time tissue preparation. Under mild anaesthesia, laparotomy incision was made and the uteri excised at the cervical and ovarian ends respectively. The uteri were freed of fats and extraneous tissues, and immediately placed in a Petri dish containing freshly prepared Krebs physiological salt solution. Approximately $1 \mathrm{~cm}$ of the uterine strips in each case was mounted in $35 \mathrm{ml}$ Organ bath thermostatically maintained at $37^{\circ} \mathrm{C}$, and gassed with $95 \%$ Oxygen plus 5\% carbon(IV)oxide. The tissue at one end was attached to an isotonic electronic force transducer, connected to an Oscillograph; while the other end was suspended in the organ bath. About 30 minutes was allowed for the development of stable, rhythmic, spontaneous contractions of the tissues. The extract or standard drugs at different concentrations were then applied, allowed to act for 3-5 minutes and the responses recorded. The tissues were sufficiently washed with fresh Krebs solution in preparation of each subsequent experiment, if need be. The concentration of both the extract and the standard drugs is a reflection of the final nutrient bath concentration.

Determination of Dose-Response relationship and $\mathrm{EC}_{50}$

Graded concentrations of the extract, ranging from 0.035 to $2.24 \mathrm{mg} / \mathrm{ml}(0.035,0.07,0.14,0.28,0.56,1.12$, and $2.24 \mathrm{mg} / \mathrm{ml}$ ) were applied to the tissues and the responses recorded. The graph of the amplitude of the response (in millimeter) was plotted against respective concentrations. From the graph, the $\mathrm{EC}_{50}$ was calculated.

\section{Determination of Possible Mechanism of Action of EFEPN}

The following drugs were used as receptor agonists or antagonist: Verapamil (0.02 - $0.2 \mu \mathrm{mol})$, Salbutamol (0.2 $\mu \mathrm{mol})$, Isoprenaline $(0.1 \mu \mathrm{mol})$, Adrenaline $(9.1 \mathrm{nmol})$, Propranolol $(1.0 \mu \mathrm{mol})$, and Prazosin $(10.0 \mathrm{nmol})$. The responses recorded were carefully traced on to a clean tracing paper. 
Percentage yield of the extracts

\section{Results}

Percentage yield $(\mathrm{w} / \mathrm{w})$ for the petroleum ether extract and the aqueous ethanolic extract were $2.18 \%$ and $9.44 \%$ of the dry matter, respectively.

\section{Dose-response relationship and $\mathrm{EC}_{50}$}

The result of the amplitude of contractile response elicited by graded concentrations of the extract on the isolated uterine muscle strips is presented in Fig. 1. The result showed that the myometrial response to EFEPN $(0.035-0.28 \mathrm{mg} / \mathrm{ml})$ was forceful and concentration dependent. The effective concentration $\left(\mathrm{EC}_{50}\right)$ was 0.056 $\mathrm{mg} / \mathrm{ml}$, with $0.035 \mathrm{mg} / \mathrm{ml}$ as the lowest active concentration (Fig.1). Conversely, EFEPN at the concentration range $0.56-2.24 \mathrm{mg} / \mathrm{ml}$ precipitated a reduction in the amplitude of the contraction until it decayed towards the baseline at the concentration of $2.24 \mathrm{mg} / \mathrm{ml}$. The effective concentration $\left(\mathrm{EC}_{50}\right)$ was $1.06 \mathrm{mg} / \mathrm{ml}$ (Fig.1).

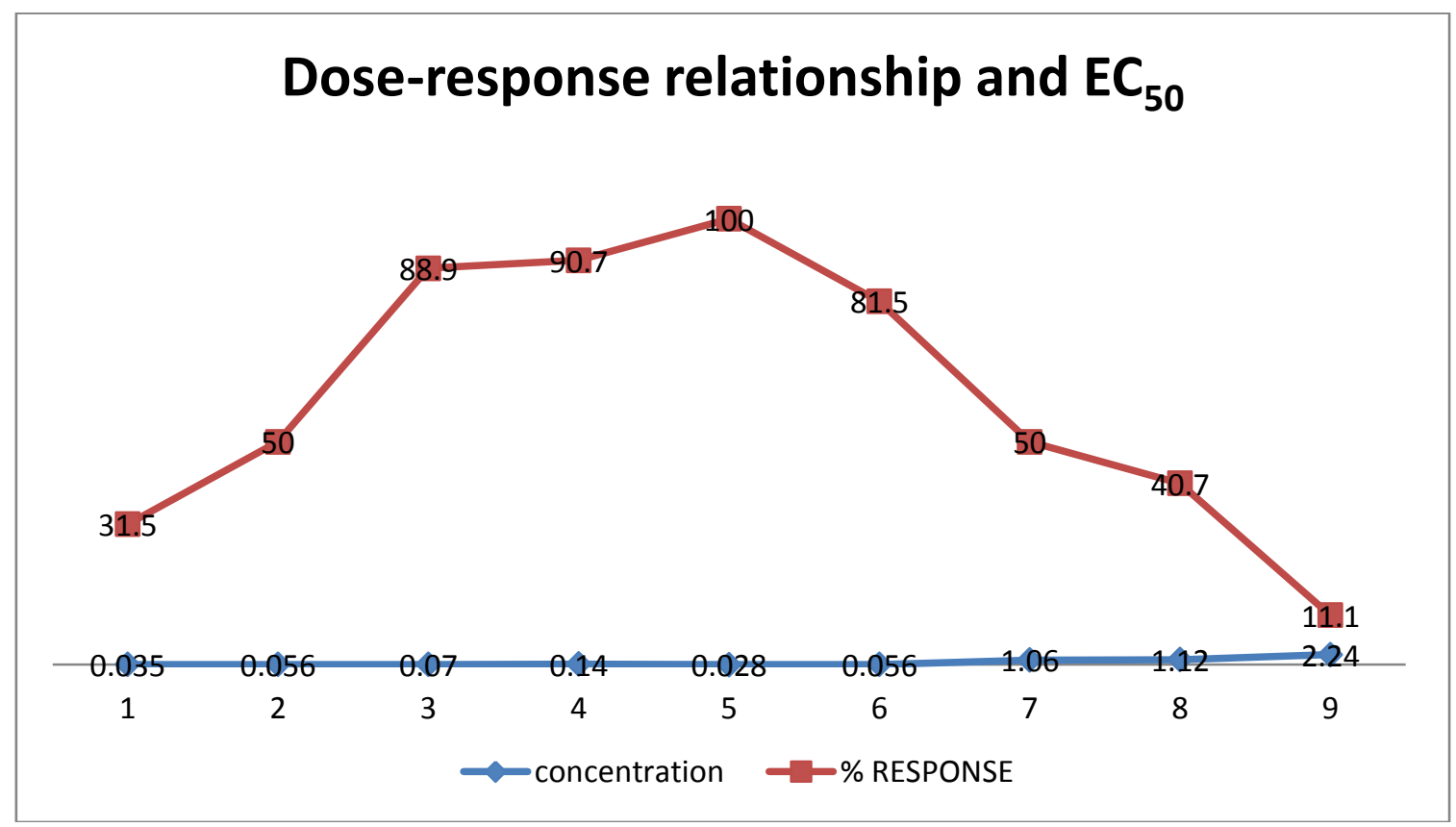

Figure 1: Effective concentration $\left(\mathrm{EC}_{50}\right)$ of the extract

\section{Role of extracellular calcium in EFEPN-induced uterine force}

The involvement of extracellular calcium in the contractile response expressed by EFEPN $(0.035-0.28 \mathrm{mg} / \mathrm{ml})$ was investigated by a deliberate removal of $\mathrm{ca}^{2+}$ from the incubation medium. The result revealed a marked reduction, both in amplitude and frequency of myometrial responses to the extract (Fig.2).

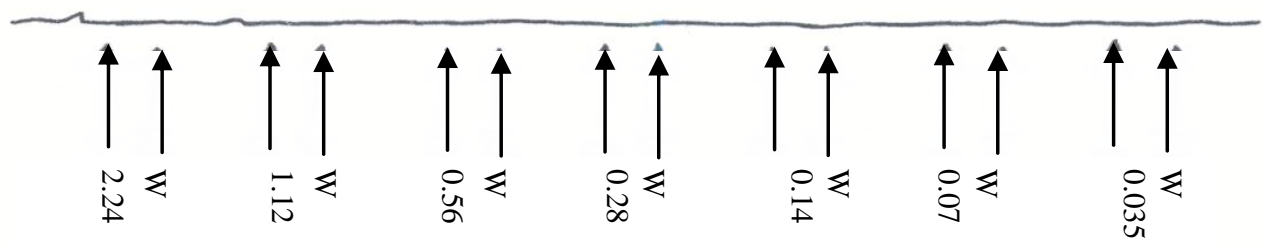

Figure 2: Response in physiological salt solution nominally devoid of $\mathrm{ca} 2^{+}$

KEY: W represents the point at which the tissue was washed;

$0.035,0.07,0.14,0.28,0.56,1.12$, and 2.24 represent different concentrations $(\mathrm{mg} / \mathrm{ml})$ of the extract.

Direction of flow of contractile response is to the left 
Further evidence to validate the role of extracellular $\mathrm{ca}^{2+}$ in myometrial responses induced by EFEPN was obtained when a voltage-dependent calcium-channel blocker, verapamil $(0.02-0.2 \mu \mathrm{mol})$ was applied to the tissue in normal physiological salt solution. The result showed that the contractile effect of EFEPN $(0.07$ $\mathrm{mg} / \mathrm{ml}$ ), both in the amplitude and frequency, progressively decreased as the concentration of verapamil increased

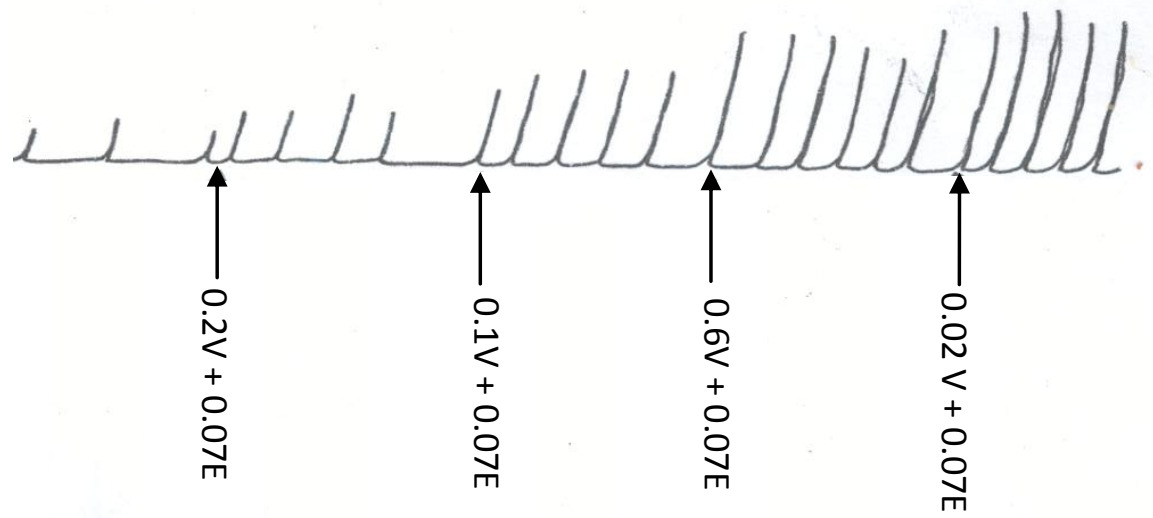

Figure 3: Responses of EFEPN in the presence of a calcium-cnannel blocker

KEY: $0.02 \mathrm{~V}, 0.06 \mathrm{~V}, 0.1 \mathrm{~V}, 0.2 \mathrm{~V}, 0.4 \mathrm{~V}=0.02 \mu \mathrm{mol}, 0.06 \mu \mathrm{mol}, 0.1 \mu \mathrm{mol}, 0.2 \mu \mathrm{mol}, 0.4 \mu \mathrm{mol}$ of verapamil respectively; $0.07 \mathrm{E}=0.07 \mathrm{mg} / \mathrm{ml}$ of extract. Direction of flow of contractile response is to the left

It was also observed that, repeated depolarization of the muscle cell membrane, using $\mathrm{KCl}(140 \mathrm{mmol})$ resulted in a strong phasic contraction that was replaced by a tonic contraction, for approximately 3 minutes, when EFEPN $(0.14 \mathrm{mg} / \mathrm{ml})$ was added (Fig.4).

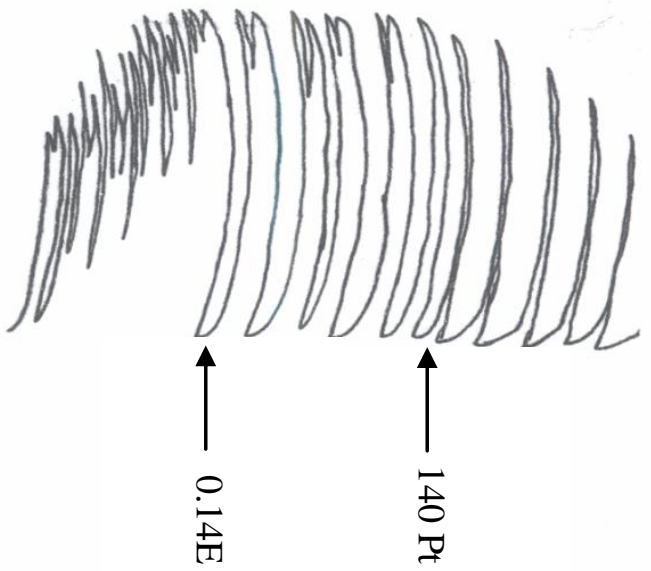

Figure 4: Response following potassium depolarization

KEY: $140 \mathrm{Pt}=140 \mathrm{mmol}$ of potassium chloride; $0.14 \mathrm{E}=0.14 \mathrm{mg} / \mathrm{ml}$ of EFEPN

Direction of flow of contractile response is to the left

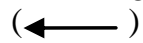

Involvement of adrenoceptors in EFEPN-modulated contractility

Investigations were made to ascertain whether the EFEPN-induced development of uterine tone was mediated via the adrenergic receptors pathways. The result showed that the application of selective $\beta$-adrenergic receptor agonist, salbutamol $(0.2 \mu \mathrm{mol})$ and adrenaline $(9.1 \mathrm{nmol})$, followed simultaneously by EFEPN $(0.07 \mathrm{mg} / \mathrm{ml})$ resulted in complete (100\%) abolition of EFEPN-induced increases in uterine contractility (Fig.5 a \& b). On the 
other hand, non-selective $\beta$-adrenergic receptor agonist, isoprenaline $(0.1 \mu \mathrm{mol})$ resulted in $73.7 \%$ inhibition (both in frequency and amplitude) of EFEPN-induced myometrial contraction (Fig.5c). It was also observed that the $\beta$-adrenergic receptor antagonist, propranolol $(0.3 \mu \mathrm{mol})$ was able to potentiate the EFEPN $(0.07 \mathrm{mg} / \mathrm{ml})$ induced contraction (Fig.5d). Furthermore, a specific $\alpha$-adrenergic receptor antagonist, Prazosin $(10 \mathrm{nmol})$ applied 2 minutes prior to the introduction of the extract $(0.07 \mathrm{mg} / \mathrm{ml})$, greatly attenuated EFEPN- induced myometrial contractility (Fig.5e).
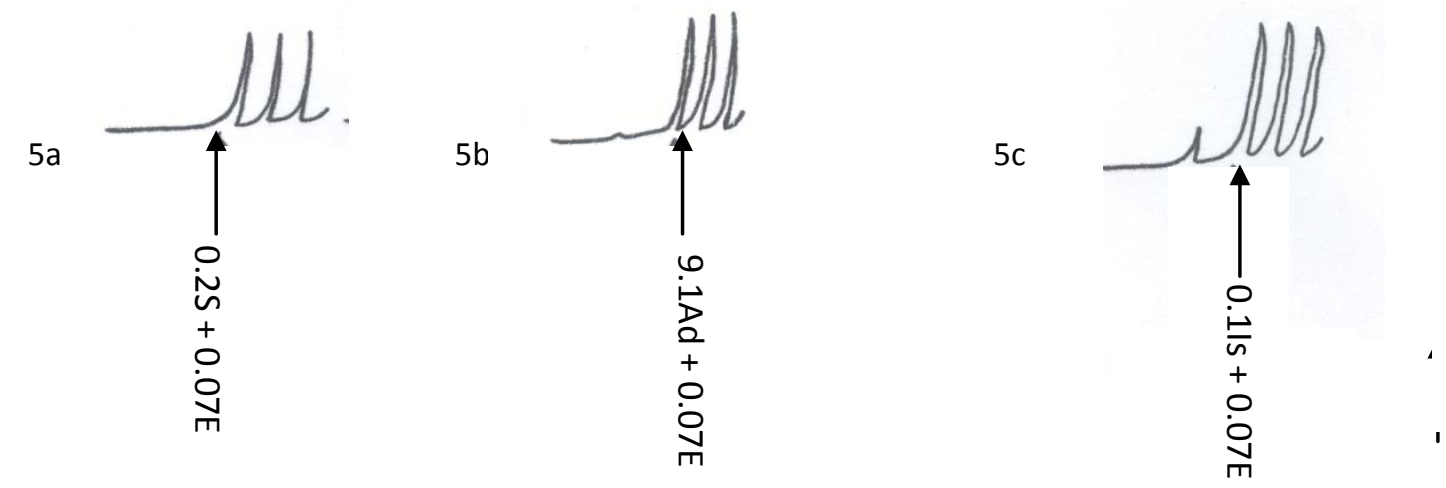

$5 d$

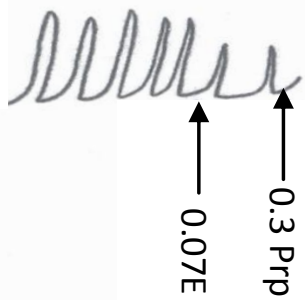

$5 \mathrm{e}$

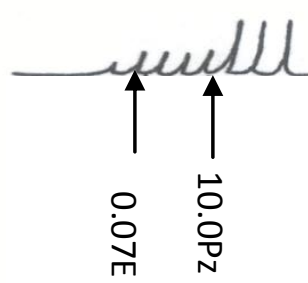

Figure 5: Effects of adrenoceptor stimulants and blockers

KEY: $0.2 \mathrm{~S}+0.07 \mathrm{E}=0.2 \mu \mathrm{mol}$ of salbutamol plus $0.07 \mathrm{mg} / \mathrm{ml}$ of EFEPN; $9.1 \mathrm{Ad}+0.07 \mathrm{E}=9.1 \mathrm{nmol}$ of adrenaline plus $0.07 \mathrm{mg} / \mathrm{ml}$ of EFEPN; 0.1Is $+0.07 \mathrm{E}=0.1 \mu \mathrm{mol}$ of isoprenaline plus $0.07 \mathrm{mg} / \mathrm{ml}$ of EFEPN; 0.3 Prp $=0.3 \mu \mathrm{mol}$ of propranolol; $10.0 \mathrm{Pz}=10 \mathrm{nmol}$ of Prazosin; $0.07 \mathrm{E}=0.07 \mathrm{mg} / \mathrm{ml}$ of EFEPN.

Direction of flow of contractile response is to the left

\section{Discussion}

The result revealed that the extract induced myometrial contraction in isolated uterine muscle strips in a concentration-dependent manner, at concentrations ranging from $0.035-0.28 \mathrm{mg} / \mathrm{ml}$. On the other hand, concentrations higher than the above stated range resulted in a progressive abolition of uterine contraction. Pseudo-akuammigine, an alkaloid isolated from Picralima nitida, which acts as an indirect reversible and competitive parasympathomimetic has been shown to express a similar pattern of contractility. In low doses it excites and in high doses it inhibits the central nervous system, respiration, contraction of the skeletal muscles and contraction of the smooth muscles (Nyunaï and Njifutié, 2006). The abolition of uterine contractions at concentrations above $0.28 \mathrm{mg} / \mathrm{ml}$ could also be attributed to desensitization of the receptor sites or due to tissue toxicity.

Therefore, myometrial relaxation following high doses of this extract (which contains pseudo-akuammigine), and possibly receptor sites desensitization may contribute to the relief of dysmenorrhea reported in traditional medicine.

It has been established that influx of calcium ions or mobilization of extracellular calcium ions is a major pathway employed by most contractants for a maximum development of uterine tone (Arrowsmith, et al. 
2010). This is achieved through depolarization of the muscle cell membrane and opening of the calcium channels, with resultant rapid entry of extracellular calcium into the intracellular compartment (Morgan, 1990; Uehata, 1997). Calcium can also be mobilized from intracellular storage sites, such as the sarcoplasmic reticulum in the absence of extracellular $\mathrm{Ca}^{2+}$, and hence elicit myometrial contraction. However, in a nominally calcium-free medium, it was observed that the extract did not initiate any contractile response. Also, when the calcium channels were deliberately blocked by verapamil $(0.02-0.2 \mu \mathrm{mol})$, the contractile response produced by a fixed concentration of the extract $(0.07 \mathrm{mg} / \mathrm{ml})$ decreased progressively as the concentration of verapamil increased. From these double-proof observations, it was established that the development of uterine contraction induced by this extract largely relied on the influx of extracellular calcium, but not likely from the intracellular $\mathrm{Ca}^{2+}$ stores.

Extracellular solutions containing high concentrations of potassium ions are known to depolarize the cell membrane and consequently lead to an increase in intracellular calcium, primarily by influx of calcium through the voltage gated calcium channels (Mendonça-Silva, et al, 2006). In this study, a repeated exposure to high potassium ion depolarization gave rise to a phasic type of contractions which were replaced by a sustained tonic component when $0.07 \mathrm{mg} / \mathrm{ml}$ of the extract was added (Fig. 4). This result further confirms the fact that EFEPN mobilizes calcium ions through a depolarized myocyte membrane.

The extract $(0.07 \mathrm{mg} / \mathrm{ml})$ did not reinstate the spontaneous myometrial contraction previously abolished by adrenaline $(9.1 \mathrm{nmol})$ and a selective $\beta$-adrenergic receptor agonist, salbutamol $(0.2 \mu \mathrm{mol})$ respectively. This shows that the extract lacks the capability to reverse the inhibition of contraction caused by adrenaline and salbutamol. This could be attributed to failure of the extract to reduce the elevated levels of cytosolic cyclic adenosine monophosphate (cAMP) and extrusion of calcium ions induced by these relaxants (Meldolesi, et al., 1991). It could also be due to inability of the extract to compete favourably with these agonists at the $\beta$ adrenergic receptor sites. However, about $26.3 \%$ contraction was observed when a non-selective $\beta$-adrenergic stimulant, isoprenaline $(0.1 \mu \mathrm{mol})$ was added simultaneously with the extract $(0.07 \mathrm{mg} / \mathrm{ml})$. This suggests that this extract may have exerted a level of inhibitory effect on this agonist, either by competition for receptor sites or through reduction of the elevated levels of cytosolic cyclic adenosine monophosphate (cAMP) (Meldolesi, et al., 1991). This could be true because the extract $(0.07 \mathrm{mg} / \mathrm{ml})$ potentiated, both in amplitude and frequency the contractile response initially evoked by a standard $\beta$-adrenoceptor blocker, propranolol $(0.3 \mu \mathrm{mol})$.

It has been well established that $\alpha$-adrenoceptors stimulation initiates, while blockage abolishes smooth muscle contractions (Riemer et al., 1987). Stimulation of $\alpha-1$ receptors enhances cAMP phosphodiesterases activity, while stimulation of $\alpha-2$ receptors inhibits adenylate cyclase activity, thereby decreasing the cytosolic cAMP, a condition necessary for contraction to take place (Yvonne, et al., 1988). In this experiment, it was observed that when these receptors were selectively blocked by prazosin $(10 \mathrm{nmol})$, the spontaneous contractions were greatly attenuated and there was no contractile response with the introduction of the extract $(0.07 \mathrm{mg} / \mathrm{ml})$. Therefore, the extract might have elicited the observed myometrial contractility through the stimulation of the $\alpha-1$ adrenergic receptors, possibly by enhancing cAMP phosphodiesterases activity.

In conclusion, EFEPN induced myometrial contraction mainly through the influx of extracellular calcium and stimulation of the $\alpha$-adrenergic receptors.

\section{References}

[1]. Adjanohoun, JE, Aboubakar, N, Diamante, K, Ebot, ME, Ekpere, JA, Enow-Orock, EG, Focho, D, Gbile, ZO, Kamanyi, A, Kamsu, KJ, Keita, A, Mbenkum, T, Mbi, CN, Mbiele, AL, Mbome, IL, Mubiru, NK, Nancy, WL, Nkongmeneck, B, Satabie, B, Sofowora, A, Tamze, V and Wirmum, CK (1996). Contribution to ethnobotanical and floristic studies in Cameroon, Traditional Medicine and Pharmacopoeia. Technical and Research Commission of the Organisation of African Unity (OAU/STRC), pp 60-61.

[2]. Aguwa, CN, Ukwe, CV, Inya-Agha, SI and Okonta, JM (2001). Antidiabetic effect of Picralima nitida aqueous seed extract in experimental rabbit model. Journal of Natural Remedies 1 2:135-139.

[3]. Arrowsmith, S, Kendrick, A and Wray, S (2010). Drugs acting on the pregnant uterus. Obstetrics, Gynaecology and Reproductive medicine. Vol. 20, issue 88. Pp. 241-247

[4]. Bulletti, C, De Ziegler, D, Polli, V, Diotallevi, L, Del Ferro, E and Flamigni, C (2000). Uterine contractility during the menstral cycle. Human Reprod. 15 Suppl 1:81-89.

[5]. Duwiejua, M, Woode, E and Obiri, DD (2002). Pseudo-akuammigine, an alkaloid from Picralimanitida seeds, has antiinflammatory and analgesic actions in rats. Journal of Ethnopharmacology 81:73-79.

[6]. Ezeamuzie, IC, Ojinnaka, MC, Uzogara, EO and Oji, SE (1994). Anti-inflammatory, antipyretic and anti-malarial activities of a West African medicinal plant - Picralima nitida. African Journal of Medicine and Medical Sciences. 23(1): 85-90.

[7]. Fakeye, TO, Itiola, OA, George, AO and Odelola, HA (2004). Antimicrobial property of Picralima nitida stem bark extract in cream formulations. Pharmaceutical Biology 42(4-5): 274-279.

[8]. François, G, Ake-Assi, L, Holenz, J and Bringmann, G (1996). Constituents of Picralima nitida display pronounced inhibitory activities against asexual erythrocytic forms of Plasmodium falciparum in vitro. Journal of Ethnopharmacology 54: $113-117$.

[9]. Iwu, MM, Jackson, JE, Tally, JD and Klayman, DL (1992). Evaluation of plant extracts for antileishmanial activity using a mechanism-based radiorespirometricmicrotechnique (RAM). PlantaMedica 58(5):436-441.

[10]. Jiofack, T, Ayissi, 1, Fokunang, C, Guedje, N and Kemeuze, V (2009). Ethnobotany and phytomedicine of the upper Nyong valley forest in Cameroon. African Journal of Pharmacy and Pharmacology 3(4):144-150. 
[11]. Kouitcheu, MLB, Penlap, BV, Kouam, J, Bonaventure, TN, Fomum, ZT and Etoa FX (2006). Evaluation of Antidiarrhoeal activity of the fruit-rind of Picralima nitida (Apocynaceae), Afr.J. Trad. CAM 3(4):66 - 73.

[12]. Kouitcheu, MLB (2007). Evaluation of antidiarreic properties and toxicity of Cylecodicus gabunensis (Mimosaceae) and Picralima nitida (Apocynaceae), plants used in the treatment of diarrhea. Ph.D Thesis in biochemistry, University of Yaoundé, Yaoundé, Cameroun. pp. 167-274.

[13]. Meldolesi, J, Clementi, E, Fasolato, C, Zacchetti, D, and Pozzan, T (1991). Ca ${ }^{2+}$ influx following receptor activation. Trends Pharmac. Sci. 12, 289-292.

[14]. Mendonça-Silva, DL, Novozhilova, E, Cobbett, PJ, Silva, CL, Noël, F, Totten, MI, Maule, AG and Day, TA (2006). Role of calcium influx through voltage-operated calcium channels and of calcium mobilization in the physiology of Schistosoma mansoni muscle contractions. Journal of Parasitology 133(1):67-74.

[15]. Menzies, JRW, Paterson, SJ, Duwiejua, M and Corbett, AD (1998). Opioid activity of alkaloids extracted from Picralima nitida (fam. Apocynaceae). European Journal of Pharmacology 350(1):101-108.

[16]. Morgan, K (1990). The role of calcium in the control of vascular tone as assessed by the $\mathrm{Ca}^{++}$indicator Aequorin. Cardiovasc Drugs Ther 4:1355-1362.

[17]. Nyunaï, N and Njifutié, N (2006). Picralima nitida (Stapf) T.Durand\&H.Durand. [Internet] Record from Protabase. Schmelzer, G.H. \&Gurib-Fakim, A. (Editors).PROTA (Plant Resources of Tropical Africa / Ressources végétales de l'Afriquetropicale), Wageningen, Netherlands.

[18]. Obiri, DD (1997). Studies on anti-inflammatory activity of extracts of seeds of Picralima nitida. M. Pharm. degree thesis, Department of Pharmaceutical Chemistry, Faculty of Pharmacy, Kwame Nkrumah University of Science and Technology, Kumasi, Ghana. pp. 139

[19]. Pierre, W, Esther, N, Pepin, A, Telesphore, B and Albert, K (2010). Evaluation of In vitro Uterotonic Activities of Fruit Extracts of Ficus asperifolia in Rats. Evidence-Based Complementary and Alternative Medicine. 2011:783413

[20]. Population Reference Bureau Staff Transitions in world population (2004). 59:1-43.

[21]. Riemer, RK, Goldfien, A, Roberts, JM, (1987). Rabbit rnyometrial adrenergic sensitivity is increased by estrogen but is independent of changes in alpha adrenoreceptor concentration. J Pharmacol Exp Ther 240:44-50

[22]. Uehata, M, Ishizuki, T, Satoh, H, Ono, T, Kawahara, T, Morishita, T, Tamakawa, H, Yamagami, K, Inui, J, Maekawa, M and Narumiya, S (1997). Calcium sensitization of smooth muscle mediated by a Rho-associated protein kinase in hypertension. Nature 389:990-994.

[23]. Wosu, LO and Ibe, CC (1989). Use of extracts of Picralima nitida bark in the treatment of experimental trypanosomiasis: a preliminary study. Journal of Ethnopharmacology 25(3):263-268.

[24]. Yvonne YW, Alan G, \& James MR (1988). Alpha adrenergic stimulation reduces cyclic adenosine 3' 5' -monophosphate generation in rabbit myometrium by two mechanisms. Biology of reproduction 39:58-65. 